Otentik's: Jurnal Hukum Kenotariatan (Vol 3, No. 1, Januari 2021)

p-ISSN 2655-5131 e-ISSN 2685-3612

\title{
DISPARITAS PUTUSAN MAJELIS PENGAWAS PUSAT NOTARIS YANG MEMILIKI KEKUATAN HUKUM MENGIKAT DALAM PENJATUHAN SANKSI ADMINISTRATIF NOTARIS \\ ( Studi Kasus Putusan No. 03/B/MPPN/X/2018 dan Putusan No. 13/B/MPPN/XII/2017)
}

\author{
MAHEKSI DIAH AYU SARASWATI \\ Magister Kenotariatan, Fakultas Hukum, Universitas Pancasila \\ Maheksidiah.79@gmail.com
}

\begin{abstract}
ABSTRAK
Majelis Pengawas Pusat Notaris berkewajiban untuk melaksanakan pengawasan dan pembinaan terhadap Notaris. Putusan yang dikelurakan oleh Majelis Pengawas Pusat Notaris merupakan putusan yang final dan incraht yang telah disahkan oleh Kementrian Hukum dan Hak Asasi Manusia. Pada hakikatnya notaris yang melanggar Pasal 16 Ayat 1 huruf a Undang-Undang Jabatan Notaris, akan dijatuhi sanksi administrative bedasarkan Pasal 85 Undang-Undang Jabatan Notaris. Namun, karena tidak ada kualifikasi sanksi minimum dan sanksi maksimum yang diatur didalam Undang-Undang jabatan Notaris, sering ditemukan disparitas atau perbedaan yang cukup signifikan didalam penjatuhan sanksi administratif di dalam putusannya. Hal ini terjadi pada kasus Putusan No. 03/B/MPPN/X/2018 dan Putusan No. 13/B/MPPN/XII/2017. Notaris bernama MB, berkedudukan di Kabuaten Cibinong dan Notaris bernama D, berkedudukan di Kota Bandung. Kedua-duanya dinyatakan melakukan perbuatan tercela yang melanggar Kode etik dan Undang-Undang Jabatan Notaris dan dinyatakan melanggar Pasal 16 Ayat 1 huruf a Undang-Undang Jabatan Notaris. Dan Atas perbuatannya notaris D dalam Putusannya No. 03/B/MPPN/X/2018 dijatuhi sanksi administratif yaitu pemberhentian dengan hormat dan Notaris MB dalam Putusan Nomor 13/B/MPPN/XII/2017 dijatuhi sanksi administrative yaitu pemberhentian sementara selama 3 bulan. Berdasarkan hal tersebut maka permasalahan yang akan diteliti dalam peneltian ini adalah: Untuk mengetahui dan menganalisis kekuatan hukum mengikat putusan Majelis Pengawas Pusat Notaris terhadap pelanggaran UUJN dan Kode etik dan yang dilakukan Notaris dan pertimbangan Majelis Pengawas Pusat Notaris dalam Penjatuhan sanksi kepada notaris dalam Putusan No.
\end{abstract}


Otentik's: Jurnal Hukum Kenotariatan (Vol 3, No. 1, Januari 2021)

p-ISSN 2655-5131 e-ISSN 2685-3612

03/MPPN/X/2018 dan Putusan No. 13/B/MPPN/XII/2017. Pada ${ }^{1}$ penelitian ini, metode yang digunakan yaitu secara yuridis normative karena menggunakan data primer sebagai sumber utama sedangkan spesifikasi penelitian bersifat deskriptif analitis dengan menggambarkan pelaksanaan dan permasalahan seputar disaparitas putusan Majelis Pengawas Pusat Notaris dalam penjatuhan sanksi administratif. Tahap penelitian dilakukan dengan cara kepustakaan dan studi lapangan, dan Teknik Penyajian Data yang dilakukan secara yuridis kualitatif. Teori yang dipakai penulis menggunakan teori keadilan. Hasil dari penelitian ini menunjukan bahwa kekuatan hukum mengikat putusan Majelis Pengawas Pusat Notaris hanya mengatur hal-hal administraif atau Etik dari profesi notaries saja. Hal ini dapat dilihat bahwa Undang-Undang Jabatan Notaris dan Kode Etik Notaris hanya mengatur penjatuhan sanksi administratif dan tidak mengatur sanksi pidana. Dan pertimbangan Majelis Pengawas Pusat Notaris dalam putusan No. 03/B/MPPN/X/2018 dan Putusan No. 13/B/MPPN/XII/2017 adalah pertimbangan berat dan ringannya kesalahan yang dilakukan oleh kedua notariss dan fakta-fakta hukum yang muncul didalam persidangan.

Kata kunci: Disparitas, Majelis Pengawas Pusat Notaris, Sanksi Administratif Notaris

\begin{abstract}
The Notary Central Supervisory Board is obliged to carry out supervision and guidance of the Notary. Decisions made by the Notary Center Supervisory Board are final and inclusive decisions that have been ratified by the Ministry of Law and Human Rights. In essence the notary who violates Article 16 Paragraph 1 letter a of the Notary Position Act, will be subject to administrative sanctions based on Article 85 of the Notary Position Act. However, because there are no minimum sanctions qualifications and maximum sanctions stipulated in the Act of Notary position, disparities or significant differences are often found in the imposition of administrative sanctions in the decisions. This happened in the case of Decision No. 03 / B / MPPN / X / 2018 and Decision No. 13 / B / MPPN / XII / 2017. Notary named MB, domiciled in Cibinong District and Notary named D, domiciled in the city of Bandung. Both are declared to have committed a disgraceful act that violated the Code of Ethics and the Act of Notary Position and were declared violating Article 16 Paragraph 1 letter a Act of Notary Position. And for his actions
\end{abstract}


Otentik's: Jurnal Hukum Kenotariatan (Vol 3, No. 1, Januari 2021)

p-ISSN 2655-5131 e-ISSN 2685-3612

notary D in his Decision No. 03 / B / MPPN / X / 2018 are subject to administrative sanctions, namely respectful dismissal and MB Notary in Decision Number 13 / B / MPPN / XII / 2017 subject to administrative sanctions, namely a temporary termination of 3 months. Based on this, the problems that will be examined in this research are: To find out and analyze the legal force binding the decision of the Notary Center Supervisory Board on violations of UUJN and the Code of Ethics and Notaries and the Notary Central Supervisory Board's consideration in imposing sanctions on notaries in Decision No. 03 / MPPN / X / 2018 and Decision No. 13 / B / MPPN / XII / 2017. In this study, the method used is juridically normative because it uses primary data as the main source while the research specification is descriptive analytical by describing the implementation and problems surrounding the disaparitas of the decision of the Notary Central Supervisory Board in the imposition of administrative sanctions. The research phase is carried out by means of literature and field studies, and Data Presentation Techniques carried out in a qualitative juridical manner. The theory used by the author uses the theory of justice. The results of this study indicate that legal force binds the decisions of the Central Notary Supervisory Board to only regulate administrative or ethical matters of the profession of notaries. It can be seen that the Act of Notary Position and Notary Ethics Code only regulates administrative sanctions and does not regulate criminal sanctions. And the consideration of the Notary Central Supervisory Board in the decision No. 03 / B / MPPN / X / 2018 and Decision No. 13 / B / MPPN / XII / 2017 is a consideration of the severity and severity of mistakes made by both notariss and legal facts that appear in the trial.

Keywords: Disparitas, Notary Central Supervisory Council, Notary Administrative Sanctions

\section{PENDAHULUAN}

Notaris merupakan salah satu profesi yang cukup disegani dan diakui di dalam masyarakat. keberadaan institusi notaris didasarkan pada peraturan Perundang-undangan yang berlaku. Berdasarkan Undang-Undang Nomor 2 tahun 2014 tentang Perubahan Atas UndangUndang Nomor 30 Tahun 2004 Tentang Jabatan Notaris (selanjutnya akan di sebut UUJN), pengertian notaris tercantum didalam pasal 1 angka 1 UUJN, yang berbunyi : 
Otentik's: Jurnal Hukum Kenotariatan (Vol 3, No. 1, Januari 2021)

p-ISSN 2655-5131 e-ISSN 2685-3612

“ Notaris adalah pejabat umum yang berwenang untuk membuat akta autentik dan memiliki kewenangan lainnya sebagaimana dimaksud didalam Undang-Undang ini atau bedasarkan Undang-Undang lainnya.”

Kedudukan profesi notaris disebut sebagai Officium nobile yaitu profesi hukum yang mulia. Dalam menjalankan profesinya seorang notaris sebagai pejabat umum harus senantiasa menjunjung tinggi harkat dan martabatnya. Notaris dituntut harus cermat, mengedepankan prinsip kehati-hatian, selalu obejktif terhadap siapapun yang datang dan sebagai profesi yang mendiri seorang notaris dalam menjalankan kewajibannya harus diikuti dengan tanggung jawab.

Notaris telah dijelaskan mempunyai peran sebagai pejabat umum yang tentunya sebagai pejabat memiliki tanggung jawab yang penting yakni melaksanakan kepercayaan yang diberikan oleh masyarakat yang dilayaninya. Seorang notaris dituntut untuk melaksanakan tugasnya dengan sebaikbaiknya serta amanah dalam melaksanakan tugasnya. Fungsi moral ini haruslah dilaksanakan oleh notaris, oleh karena jabatan notaris merupakan jabatan kepercayaan maka seorang notaris harus memiliki perilaku yang baik.

Mengingat besarnya tanggung jawab kepercayaan yang diemban notaris maka seorang notaris harus berpegang teguh kepada Kode etik dan UUJN dan juga berkewajiban menegakkan Kode etik dan UUJN dan memiliki perilaku profesional (profesional behavior) yakni integritas moral, menghindari sesuatu yang tidak baik, jujur, teliti, cermat, sopan santun, tidak sematamata karena pertimbangan uang dan berpegang teguh pada Kode etik profesi dimana didalamnya diatur segala perilaku yang harus dimiliki oleh seorang notaris. Maka seorang Notaris berkewajiban untuk menjalankan tugas sesuai dengan Kode etik dan Perundangundangan. Kode etik dan Perundang-undangan akan membatasi kewenangan seorang notaris agar tidak sewenang-wenang dalam menjalankan tugasnya.

Mengingat pentingnya tugas yang ditanggung Notaris maka dalam menjalankan kewajibannya seorang notaris tidak hanya diaur didalam Kode etik namun juga diatur didalam UUJN. Kewajiaban Notaris diatur didalam Pasal 16 UUJN maka Notaris harus bertindak amanah, jujur, saksama, mandiri, tidak berpihak, dan menjaga kepentingan pihak yang terkait dalam perbuatan hukum.

Dewasa kini, sejalan dengan perkembangan globalisasi semakin meningkatnya kebutuhan masyarakat, seperti kebutuhan ekonomi beberapa perbuatan melawan hukum 
Otentik's: Jurnal Hukum Kenotariatan (Vol 3, No. 1, Januari 2021)

p-ISSN 2655-5131 e-ISSN 2685-3612

dilakukan untuk memenuhinya sehingga menyebabkan kerugian kepada orang lain, dan hal tersebut tidak luput terjadi pada siapapun termasuk profesi seorang Notaris. Notaris dituntut untuk menjunjung tinggi etika profesi yang telah diatur di dalam UUJN dan Kode etik, namun dalam beberapa kasus ditemukan notaris yang tidak mengindahkannya sehingga menimbulkan kerugian bagi pihak lain akibat perbuatannya.

Mekanisme dan sanksi akibat pelanggaran Kode etik dan Perundang-undangan yang akan dikenakan sanksi administratif yang dilakukan notaris telah diatur di dalam Pasal 13 Peraturan Menteri Hukum dan Hak Asasi Manusia Nomor 61 Tahun 2016 Tentang Tata Cara Penjatuhan Sanksi Administratif, yang berisikan apabila ada anggota yang diduga melakukan pelanggaran terhadap Kode etik dan Perundang-undangan, baik dugaan tersebut berasal dari pengetahuan Majelis Pengawas Daerah sendiri maupun karena laporan dari Pengurus Daerah ataupun pihak lain kepada Majelis Pengawas Daerah. Atas dasar laporan pengaduan tersebut kemudian Majelis Pengawas Daerah wajib segera mengambil tindakan dengan mengadakan sidang Majelis Pengawas Daerah untuk membicarakan dugaan terhadap pelanggaran tersebut.

Apabila menurut hasil sidang Majelis Pengawas Daerah sebagaimana yang tercantum diatas, ternyata ada dugaan kuat terhadap pelanggaran Etik tersebut, maka Majelis Pengawas Daerah berkewajiban memanggil anggota yang diduga melanggar tersebut dengan surat tercatat atau dengan ekspedisi, untuk didengar keterangannya dan diberi kesempatan untuk membela diri. Majelis Pengawas Daerah baru akan menentukan putusannya mengenai terbukti atau tidaknya pelanggaran etik serta penjatuhan sanksi terhadap pelanggarnya (apabila terbukti), setelah mendengar keterangan dan pembelaan diri dari anggota yang bersangkutan dalam sidang Majelis Pengawas Daerah.

Penjatuhan sanksi Etik ketika notaris terbukti melakukan pelanggaran yang diwajibkan atau memenuhi ketentuan-ketentuan yang dilarang oleh Kode etik dan UUJN. Penjatuhan sanksi notaris tersebut berupa sanksi Administratif yakni sanksi yang dijatuhi kepada notaris yang dapat berupa peringatan tertulis, pemberhentian sementara, pemberhentian dengan hormat dan pemberhentian dengan tidak hormat. Pejabat Majelis Pengawas Notaris berwenang menjatuhkan sanksi administratif terhadap notaris yang melakukan pelanggaran terhadap UUJN dan Kode etik. 
Otentik's: Jurnal Hukum Kenotariatan (Vol 3, No. 1, Januari 2021)

p-ISSN 2655-5131 e-ISSN 2685-3612

Putusan yang berisi penjatuhan sanksi pemecatan sementara (schorsing) atau pemecatan (onzetting) dari Majelis Pengawas Daerah dapat diajukan/dimohonkan banding kepada Majelis Pengawas Wilayah. Setelah menerima permohonan banding, Majelis Pengawas Wilayah akan memanggil para anggota yang naik banding untuk dimintai keterangan untuk kemudian Majelis Pengawas Wilayah akan memutuskan, setelah mendengar keterangan dan pembelaan diri dari anggota yang bersangkutan dalam sidang Majelis Pengawas Wilayah.

Putusan yang telah dikeluarkan oleh Majelis Pengawas Wilayah dapat diajukan/dimohonkan pemeriksaan tingkat akhir kepada Majelis Pengawas Pusat/ Majelis Pengawas Pusat Notaris. (MPPN). Prosedur yang akan dilakukan oleh Majelis Pengawas Pusat sama dengan yang sebelum-sebelumnya.

Majelis Pengawas Pusat dapat mengambil keputusan sendiri bedasarkan kebijaksanaan dan keadilan. Putusan MPPN disampaikan kepada menteri dan salinannya disampaikan kepada pelapor, terlapor, MPD, MPW, Pengurus Pusat INI, dalam jangka waktu 30 (tiga puluh) hari kalender terhitung sejak putusan diucapkan. Putusan yang dikeluarkan oleh Majelis Pengawas Pusat ini bersifat akhir atau Inchrat atau sudah tidak dapat diganggu gugat dan harus dilaksanakan oleh para pihak.

Berdasarkan Pasal 85 UUJN, sanksi yang dapat dijatuhkan terhadap Notaris yang melakukan pelanggaran Kode etik dan Perundang-undangan dapat berupa: teguran, peringatan, schorsing (pemecatan sementara), onzetting (pemecatan), pemberhentian dengan hormat dan pemberhentian dengan tidak hormat.

Majelis Pengawas Notaris Pusat adalah suatu badan yang mempunyai kewenangan dan kewajiban untuk melaksanakan pengawasan dan pembinaan terhadap Notaris bedasarkan Pasal 1 ayat 1 Peraturan Menteri Hukum dan Hak Asasi Manusia Republik Indonesia Nomor M.02. PR.08.10 Tahun 2004 Tentang Tata Cara Pengangkatan Anggota, Pemberhentian Anggota, Susunan Organisasi,Tata Kerja,Dan Tata Cara Pemeriksaan Majelis Pengawas Notaris. Dalam Pasal 77 UUJN diatur mengenai wewenang MPP yang berkaitan dengan Menyelenggarakan sidang untuk memeriksa dan mengambil keputusan dalam tingkat akhir terhadap penjatuhan sanksi dan penolakan cuti terhadap Notaris yang memiliki kekuatan hukum yang mengikat.

Putusan yang dikeluarkan Majelis Pegawas Pusat Notaris merupakan putusan yang administratif yakni sanksi yang diberikan berupa sanksi perdata, sanksi etik dan sanksi 
administratif. Batasan-batasan yang dijadikan dasar untuk memidanakan Notaris merupakan aspek formal dari akta Notaris. Jika Notaris terbukti melakukan pelanggaran dari aspek formal dapat dijatuhi sanksi perdata atau sanksi administrasi tergantung pada jenis pelanggarannya atau sanksi Kode etik dan Perundang-undangan Jabatan Notaris. Dalam aturan hukum tertentu, di samping dijatuhi sanksi administratif, juga dapat dijatuhi sanksi pidana, dalam kaitan ini UUJN dan Kode etik tidak mengatur sanksi pidana untuk Notaris yang melanggar UUJN dan Kode etik. Jika terjadi hal seperti itu maka terhadap Notaris tunduk kepada tindak pidana umum. Putusan Majelis Pengawas Pusat Notaris hanya mengikat kepada profesi atau berupa sanksi Etik dan tidak mengikat sanksi pidana.

Notaris yang melanggar Kode etik dan Perundang-undangan yang memiliki kesamaan pasal akan dijatuhi sanksi yang sama. Namun, MPPN memilki kewenangan untuk mengambil keputusan bedasarkan kebijaksanaan dan keadilan atas petimbangan berat dan ringannya kesalahan yang dilakukan oleh notaris. Pertimbangan berat dan ringannya kesalahan notaris berimplikasi kepada beratnya tanggung jawab yang harus di tanggunnya . Tidak jarang di temukan Putusan MPPN yang memiliki perbedaan amar putusan yakni penjatuhan sanksi meskipun memiliki kesamaan pasal yang dilanggar. Disparitas putusan ini didasari oleh beberapa faktor, beberapa faktornya adalah dari didalam Undang-Undang Jabata Notaris dan Kode Etik notaries tidak mengatur mengenai klasifikasi sanksi minimum dan sanksi maksimum serta perbedaan fakta hukum yang terjadi maka sudah dapat dipastikan putusan hakim akan berbeda bahkan berlawanan arah hingga terjadi disparitas dalam sanksi Etiknya.

Pada hakikatnya, notaris yang melanggar Pasal 16 Ayat 1 UUJN, Menurut Pasal 85 UUJN dijatuhi hukuman teguran lisan, teguran tertulis, pemberhentian sementara, pemberhentian dengan hormat dan pemberhentian dengan tidak hormat. Namun, Terdapat perbedaan yang signifikan pada Pemberian sanksi etik notaris dijatuhkan oleh Majelis Pengawas Pusat Notaris, perbedaan pada beratnya sanksi yang dijatuhkan kepada kedua notaris walaupun keduanya memiliki persamaan pasal yang dilanggar, yaitu pasal 16 Ayat 1 huruf a Undang Undang Jabatan Notaris.

Kasus ini dapat ditemukan pada putusan No. 03/B/MPPN/X/2018 dan Putusan Nomor 13/B/MPPN/XII/2017. Notaris bernama MB Notaris yang berkedudukan di Kabuaten Cibinong dan Notaris bernama D, Notaris yang berkedudukan di Kota Bandung. Kedua-duanya 
Otentik's: Jurnal Hukum Kenotariatan (Vol 3, No. 1, Januari 2021)

p-ISSN 2655-5131 e-ISSN 2685-3612

dinyatakan melakukan perbuatan tercela yang melanggar Kode etik dan Perundang-undangan notaris dan dinyatakan melanggar Pasal 16 Ayat 1 huruf a Dalam menjalankan jabatannya, Notaris wajib bertindak amanah, jujur, saksama, mandiri, tidak berpihak, dan menjaga kepentingan pihak yang terkait dalam perbuatan hukum. Dan Atas perbuatannya notaris dijatuhi sanksi etik oleh Majelis Pengawas Pusat Notaris dalam Putusannya No. 03/B/MPPN/X/2018 untuk Notaris D dengan sanksi Etik pemberhentian dengan hormat dan Putusan Nomor 13/B/MPPN/XII/2017 untuk notaris MB dengan sanksi Etik pemberhentian sementara selama 3 bulan.

Notaris yang telah dijatuhi sanksi etik dari MPPN, baik sanksi pemhentian sementara maupun pemecatan secara hormat atau tidak hormat, tidak di perolehkan untuk membuat akta autentik. Profesninya sebagai Notaris menjadi tidak berwenang dalam pembuatan akta autentik. Notaris tersebut tidak boleh membuat akta, apabila masih menjalankan cuti atau dipecat dari jabatannya. Akta autentik yang dibuat oleh notaris yang masih dalam masa hukuman, kekuatan hukumnya menjadi tidak sah atau dianggap tidak pernah ada.

Sanksi-sanksi merupakan bagian yang penting didalam hukum. Dengan adanya sanksi etik adalah untuk mencegah terjadinya perilaku yang tidak etis dan memberikan arah serta menjamin mutu moral anggotanya. Pemegang profesi dituntut mengutamakan profesinya secara bertanggung jawab. Meskipun perkaranya sama yang dilanggar pasalnyapun sama tetapi tidak jarang penjatuhan sanksinya berbeda, seperti penjatuhan sanksi notaris yang melanggar Pasal 16 huruf A yang dijatuhi sanksi oleh MPPN. Perbedaan penjatuhan sanksi didalam putusan MPPN menjadi urgent, karena menimbulkan ketidakadilan terhadap penjatuhan sanksi didalam profesi notaris tersebut. Keadilan dalam penjatuhan sanksi merupakan kewajiban yang harus ditegaskan dalam peraturan hukum menjaga keharmonisan dan keselarasan didalam hubungan profesi notaris.

Masalah berikutnya tidak hanya mengenai disparitas putusan MPPN, namun meskipun Putusan MPPN bersifat final/inchract, mengikatnya putusan tersebut kepada notaris yang melanggar Kode etik dan Perundang-undangan, Namun terdapat perbedaan penjatuhan sanksi yang dikeluarkan oleh MPPN yakni notaris yang melanggar pasal yang sama yakni, Pasal 16 Ayat a namun memiliki perbdaan dalam penjatuhan sanksinya. Perbedaan tersebut ketika 
masing-masing notaris mendapat sanksi pemecatan sementara selama 3(tiga) bulan dan pemberhentian dengan hormat.

Berdasarkan uraian yang telah disebutkan terdapat permasalahan yang perlu dikaji lebih lanjut mengenai disparitas putusan MPPN dan kekuatan hukum mengikat Putusan MPPN sehingga saya tertarik untuk mengajukan penelitian dalam bentuk Tesis dengan judul "DISPARITAS PUTUSAN MAJELIS PENGAWAS PUSAT NOTARIS YANG MEMILIKI KEKUATAN HUKUM MENGIKAT DALAM PENJATUHAN SANKSI ADMINISTRATIF NOTARIS ( Studi Kasus Putusan No. 03/B/MPPN/X/2018 dan No. 13/B/MPPN/XII/2017)".

\section{KAJIAN TEORI}

Kerangka teori terdiri atas dua kata,yaitu kerangka dan teori. Kerangka teori secara etimoogi dalam KBBI adalah rangka (tulang belulang), garis besar, rancangan. Adapun pengertian eori secara etimologi adalah pendapat yang didasarkan pada penelitian dan penemuan. Fungsi kerangka teori adalah meramalkan atau memprediksi jawaban atas permasalahan penelitan. Teori hukum yang penulis gunakan dalam penelitian tesis ini adalah teori keadilan.

Istilah keadilan (iustitia) berasal dari kata "adil" yang berarti: tidak berat sebelah, tidak memihak, berpihak kepada yang benar, sepatutnya, tidak sewenang-wenang. Dari beberapa definisi dapat disimpulkan bahwa pengertian keadilan adalah semua hal yang berkenan dengan sikap dan tindakan dalam hubungan antar manusia, keadilan berisi sebuah tuntutan agar orang memperlakukan sesamanya sesuai dengan hak dan kewajibannya, perlakukan tersebut tidak pandang bulu atau pilih kasih; melainkan, semua orang diperlakukan sama sesuai dengan hak dan kewajibannya.

Pandangan Aristoteles tentang keadilan bisa didapatkan dalam karyanya nichomachean ethics, politics, dan rethoric. Spesifik dilihat dalam buku nicomachean ethics, buku itu sepenuhnya ditujukan bagi keadilan, yang, berdasarkan filsafat hukum Aristoteles, mesti dianggap sebagai inti dari filsafat hukumnya, "karena hukum hanya bisa ditetapkan dalam kaitannya dengan keadilan". Pada pokoknya pandangan keadilan ini sebagai suatu pemberian hak persamaan tapi bukan persamarataan. Aristoteles membedakan hak persamaanya sesuai dengan hak proposional. Kesamaan hak dipandangan manusia sebagai suatu unit atau wadah 
yang sama. Inilah yang dapat dipahami bahwa semua orang atau setiap warga negara dihadapan hukum sama. Kesamaan proposional memberi tiap orang apa yang menjadi haknya sesuai dengan kemampuan dan prestasi yang telah dilakukanya.

John Rawls yang dipandang sebagai perspektif "liberal-egalitarian of social justice", berpendapat bahwa keadilan adalah kebajikan utama dari hadirnya institusi-institusi sosial (social institutions). Akan tetapi, kebajikan bagi seluruh masyarakat tidak dapat mengesampingkan atau menggugat rasa keadilan dari setiap orang yang telah memperoleh rasa keadilan. Khususnya masyarakat lemah pencari keadilan. Secara spesifik, Pandangan Rawls memposisikan adanya situasi yang sama dan sederajat antara tiap-tiap individu di dalam masyarakat. Tidak ada pembedaan status, kedudukan atau memiliki posisi lebih tinggi antara satu dengan yang lainnya, sehingga satu pihak dengan lainnya dapat melakukan kesepakatan yang seimbang.

Pandangan Hans Kelsen tentang keadilan bersifat positifisme, nilai-nilai keadilan individu dapat diketahui dengan aturan-aturan hukum yang mengakomodir nilai-nialai umum, namun tetap pemenuhan rasa keadilan dan kebahagian diperuntukan tiap individu. Lebih lanjut Hans Kelsen mengemukakan keadilan sebagai pertimbangan nilai yang bersifat subjektif. Walaupun suatu tatanan yang adil yang beranggapan bahwa suatu tatanan bukan kebahagian setiap perorangan, melainkan kebahagian sebesar-besarnya bagi sebanyak mungkin individu dalam arti kelompok, yakni terpenuhinya kebutuhan-kebutuhan tertentu, yang oleh penguasa atau pembuat hukum, dianggap sebagai kebutuhan-kebutuhan yang patut dipenuhi, seperti kebutuhan sandang, pangan dan papan. Tetapi kebutuhan-kebutuhan manusia yang manakah yang patut diutamakan. Hal ini apat dijawab dengan menggunakan pengetahuan rasional, yang merupakan sebuah pertimbangan nilai, ditentukan oleh faktor-faktor emosional dn oleh sebab itu bersifat subjektif. .

Sebagai aliran positivisme Hans Kelsen mengakui juga bahwa keadilan mutlak berasal dari alam, yakni lahir dari hakikat suatu benda atau hakikat manusia, dari penalaran manusia atau kehendak Tuhan. Pemikiran tersebut diesensikan sebagai doktrin yang disebut hukum alam. Doktrin hukum alam beranggapan bahwa ada suatu keteraturan hubungan-hubungan manusia yang berbeda dari hukum positif, yang lebih tinggi dan sepenuhnya sahih dan adil, karena berasal dari alam, dari penalaran manusia atau kehendak Tuhan. 
Otentik's: Jurnal Hukum Kenotariatan (Vol 3, No. 1, Januari 2021)

p-ISSN 2655-5131 e-ISSN 2685-3612

Pemikiran tentang konsep keadilan, Hans Kelsen yang menganut aliran positifisme, mengakui juga kebenaran dari hukum alam. Sehingga pemikirannya terhadap konsep keadilan menimbulkan dualisme antara hukum positif dan hukum alam. Menurut Hans Kelsen :

"Dualisme antara hukum positif dan hukum alam menjadikan karakteristik dari hukum alam mirip dengan dualisme metafisika tentang dunia realitas dan dunia ide model Plato. Inti dari fislafat Plato ini adalah doktrinnya tentang dunia ide. Yang mengandung karakteristik mendalam. Dunia dibagi menjadi dua bidang yang berbeda : yang pertama adalah dunia kasat mata yang dapa itangkap melalui indera yang disebut realitas; yang kedua dunia ide yang tidak tampak."

Pengertian keadilan menurut W.J.S Poerwadarminto yang menggemukakan bahwa pengertian keadilan ialah tidak berat sebelah yang artinya seimbang, dan yang sepatutnya tidak sewenang-wenang.

Bedasarkan pengertian-pengertian yang telah diutarakan oleh para ahli hukum, dapat ditarik kesimpulan bahwa hukum memiliki fungsi yang penting untuk mengintegrasikan dan mengkoordinasikan kepentingan-kepentingan yang bertubrukan satu sama lainnya dalam bentuk keadilan hukum. Keadilan hukum memberikan prinsip pengakuan dan perlindungan harkat dan martabat manusia yang bersumber pada prinsip Negara Hukum Indonesia yaitu Pancasila bahwa setiap warganegara memiliki derajat yang sama di mata hukum. Sehingga menimbulkan rasa aman dan terlindungi akan hak-haknya sebagai warga Negara dan menciptakan keadilan didalam masyarakat.

Norma-norma yang memajukan keadilan harus sungguh-sungguh berfungsi sebagi peraturan yang ditaati serta merupakan jaminan mengenai hukum yang berisi keadilan dan menibulkan rasa aman akan haknya di mata hukum. Keadilan hukum merupakan bagian-bagian yang tetap dari hukum dan harus diperhatikan, kepastian hukum harus dijaga demi keamanan dan ketertiban suatu Negara sehingga hukum positif harus selalu ditaati.

\section{METODE PENELITIAN}

Penelitian ini, metode yang digunakan yaitu secara yuridis normative karena menggunakan data primer sebagai sumber utama sedangkan spesifikasi penelitian bersifat deskriptif analitis dengan menggambarkan pelaksanaan dan permasalahan seputar disaparitas putusan Majelis Pengawas Pusat Notaris dalam penjatuhan sanksi administratif. Tahap penelitian 
Otentik's: Jurnal Hukum Kenotariatan (Vol 3, No. 1, Januari 2021)

p-ISSN 2655-5131 e-ISSN 2685-3612

dilakukan dengan cara kepustakaan dan studi lapangan, dan Teknik Penyajian Data yang dilakukan secara yuridis kualitatif. Teori yang dipakai penulis menggunakan teori keadilan.

\section{HASIL PENELITIAN}

Majelis Pengawas Notaris merupakan lembaga yang berwenang mengawasi notaris yang telah di tentukan didalam Pasal 67 Ayat 1 UUJN. Dalam ketentuan ini disebutkan bahwa pengawasan atas notaris dilakukan oleh menteri. Menteri yang dimaksud dalam ketentuan ini, yaitu menteri Hukum dan Hak Asasi Manusia. Didalam melakukan pengawasan, Menteri Hukum dan Hak Asasi Manusia membentuk Majelis Pengawas Notaris atau disebut dengan Majelis Pengawas. Pejabat atau majelis pengawas yang berwenang menjatuhkan sanksi administratif kepada notaris, terdiri atas: Majelis Pengawas Wilayah Notaris (MPWN), Majelis Pengawas Pusat Notaris (MPPN), dan Menteri Hukum dan Hak Asasi Manusia.

Selain melakukan pengawasan Majelis Pengawas Notaris berwenang untuk menjatuhkan sanksi Administratif kepada notaris yang melakukan pelanggaran bedasarkan Pasal $69-76$ UUJN. Dalam pasal-pasal tersebut diuraikan berbagai kewenangan Majelis dalam melakukan pengawasan serta penjatuhan sanksi administratif kepada notaris yang melanggar Kode Etik dan UUJN.

Prosedur yang dapat dilakukan ketika seseorang merasa dirugikan karena perbuatan seorang notaris yang melakukan pelanggaran hukum, antara lain membuat laporan kepada Majelis Pengawas Daerah Notaris. Notaris yang keberatan dengan hasil yang dikeluakan olah Majelis Pengawas Daerah dapat mengajukan banding kepada Majelis Pengawas Wilayah. Laporan hasil putusan Majelis Pengawas Daerah mempunyai arti yang sangat penting bagi Majelis Pengawas Wilayah Notaris karena dengan adanya laporan itu, Majelis Pengawas Wilayah Notaris dapat melakukan pemeriksaan dan menjatuhkan sanksi kepada notaris yang melakukan pelanggaran terhadap peraturan perundang-undangan yang berlaku.

Pengaturan tentang kewenangan Majelis Pengawas Wilayah Notaris dalam penjatuhan sanksi administratif, khususnya sanksi peringatan tertulis kepada notaris telah ditentukan dalam Pasal 5 Peraturan Menteri Hukum dan Hak Asasi Manusia Nomor 61 Tahun 2016 tentang Tata Cara Penjatuhan Sanksi Administratif terhadap Notaris. Di dalam ketentuan itu disebutkan bahwa Majelis Pengawas Wilayah dapat menjatuhkan sanksi peringatan tertulis kepada notaris dalam hal notaris telah melakukan delapan macam pelanggaran, sebagaimana dikemukakan 
Otentik's: Jurnal Hukum Kenotariatan (Vol 3, No. 1, Januari 2021)

p-ISSN 2655-5131 e-ISSN 2685-3612

diatas. Bedasarkan Pasal 73, UUJN (1) Prosedur Majelis Pengawas Wilayah dalam menjatuhkan sanksi kepada notaris antara lain:

1. Memanggil Notaris terlapor untuk dilakukan pemeriksaan atas laporan

2. Menyelenggarakan sidang untuk memeriksa dan mengambil keputusan atas laporan masyarakat yang disampaikan melalui Majelis Pengawas Wilayah.

3. Memeriksa dan memutus atas keputusan Majelis Pengawas Daerah yang menolak cuti yang diajukan oleh Notaris pelapor

4. Memberikan sanksi berupa teguran lisan atau tertulis;

5. Mengusulkan pemberian sanksi terhadap Notaris kepada Majelis Pengawas Pusat berupa:

a. pemberhentian sementara 3 (tiga) bulan sampai dengan 6 (enam) bulan;

b. atau pemberhentian dengan tidak hormat.

6. membuat berita acara atas setiap keputusan penjatuhan sanksi.

Setelah Majelis Pengawas Wilayah Notaris memeriksa dan memutus atas keputusan Majelis Pengawas Daerah, yang diajukan oleh Notaris pelapor, maka Majelis Pengawas Wilayah Notaris segera mengeluarkan putusan atas pertimbangan dirinya. Notaris yang merasa keberatan dengan putusan yang dikeluarkan oleh Majelis Pengawas Wilayah Notaris dapat mengajukan kasasi ke Majelis Pengawas Pusat Notaris (MPPN). Untuk kemudian Majelis Pengawas Pusat Notaris akan mengkaji kembali serta memutuskan kembali. Pengaturan tentang kewenangan Majelis Pengawas Pusat Notaris (MPPN) telah dientukan dalam Pasal 6 sampai dengan Pasal 7 Peraturan Menteri Hukum dan Hak Asasi Manusia Nomor 61 Tahun 2016 tentang Tata Cara Penjatuhan Sanksi Administratif terhadap Notaris. Notaris yang merasa keberatan dengan hasil putusan yang dikeluarkan oleh Majelis Pengawas Wilayah, dapat mengajukan kasasi kepada Majelis Pengawas Pusat Notaris. Bedasarkan Pasal 77 UUJN, Prosedur Majelis Pengawas Pusat dalam menjatuhkan sanksi kepada notaris, antara lain :

a. memanggil Notaris terlapor untuk dilakukan pemeriksaan

b. menyelenggarakan sidang untuk memeriksa dan mengambil keputusan dalam tingkat banding terhadap penjatuhan sanksi dan penolakan cuti

c. menjatuhkan sanksi pemberhentian sementara; dan mengusulkan pemberian sanksi berupa pemberhentian dengan tidak hormat kepada Menteri Hukum dan Hak Asasi Manusia. 
Otentik's: Jurnal Hukum Kenotariatan (Vol 3, No. 1, Januari 2021)

p-ISSN 2655-5131 e-ISSN 2685-3612

Majelis Pengawas Pusat Notaris kemudian akan merundingkan dan memutuskan, maka putusan tesebut akan dikirimkan kepada Menteri Hukum dan Hak Asasi Manusia untuk kemudian menerima dan mengesakan putusan yang dikeluarkan oleh Majelis Pengawas Pusat Notaris hal ini sesuai dengan Kewenangan Menteri Hukum dan Hak Asasi Manusia dalam pemberhentian notaris telah ditentukan dalam Pasal 10 sampai dengan Pasal 13 Peraturan Menteri Hukum dan Hak Asasi Manusia Nomor 61 Tahun 2016 tentang Tata Cara Penjatuhan Sanksi Administratif Terhadap Notaris. Putusan yang dikeluarkan oleh Majelis Pengawas Pusat Notaris bersifat Final dan berkekuatan hukum mengikat dan incraht.

Akibat hukum Putusan yang bersifat final adalah berkekuatan hukum mengikat. Dalam hal berkeuatan hukum mengikat maka putusan langsung memperoleh kekuatan hukum tetap sejak diucapkan. Akibat hukumnya secara umum, tidak ada upaya hukum yang dapat ditempuh terhadap putusan tersebut. Sama halnya dengan putusan yang telah dikeluarkan oleh Majelis Pengawas Pusat Notaris dan telah disahkan Oleh Menteri Hukum dan Hak Asasi Manusia adalah bersifat mengikat dan berkekutan hukum tetap dan harus laksanakan oleh notaris sejak dibacakannya putusan tersebut. Namun, Notaris yang masih merasa keeratan dengan Putusan yang dikeluarkan oleh Majelis Pengawas Pusat Notaris dapat mengajukan gugatan kepada PTUN, hal ini karna putusan Majelis Pengawas Pusat Notaris merupakan poroduk lembaga pemerintah, yakni Menteri Hukum dan Hak Asasi Manusia.

Kekuatan hukum mengikat yang dimuat dalam putusan Majelis Pengawas Pusat Notaris hanya mengatur mengenai etiknya saja, yakni hanya profesi notaris itu saja. Hal tersebut dapat dilihat pada penjatuhan sanksi-sanksi yang telah diatur di dalam Kode Etik dan UUJN. penjtuhan sanksi yang diatur di dalam UUJN dan Kode Etik Notaris hanya sebagatas menjatuhkan sanksi administratif saja, yakni Peringatan tertulis, Pemberhentian sementara, Pemberhentian dengan hormat dan Pemberhentian dengan tidak hormat. Kode Etik dan UUJN tidak menatur dan memuat mengenai penjatuhan sanksi pidana seorang notaris yang melanggar kewajibannya.

UUJN dan Kode Etik Notaris telah mengatur sanksi yang dapat dijatuhkan kepada notaris yang melanggarnya. Sanksi-sanksi yang dijatuhi oleh Majelis Pengawas notaris berupa sanksi administraif. Sanksi administratif merupakan sanksi atau hukuman yang dijatuhkan kepada notaris yang telah melakukan pelanggaran terhadap Kode Etik dan peraturan perundangundangan yang berlaku. Subjek sanksi administratif, yaitu notaris. Penyebab dijatuhkannya 
Otentik's: Jurnal Hukum Kenotariatan (Vol 3, No. 1, Januari 2021)

p-ISSN 2655-5131 e-ISSN 2685-3612

sanksi itu karena melanggar peraturan perundang-undangan yang berlaku, khususnya yang berkaitan dengan UUJN dan berbagai peraturan pelaksanaannya. Sanksi administratif terdiri atas:

1. Peringatan tertulis

Peringatan tertulis merupakan teguran awal kepada notaris yang melanggar ketentuan dan Kode Etik Notaris. Bedasarkan Pasal 5 Peraturan Menteri Hukum Dan Hak Asasi Manusia Republik Indonesia Nomor 61 Tahun 2016 Tentang Tata Cara Penjatuhan Sanksi Administratif Terhadap Notaris,

2. Pemberhentian sementara

Pemberhentian sementara merupakan proses, cara atau perbuatan melepas jabatan notaris untuk sementara waktu, tidak untuk selama-lamanya. Ada lima alasan berhentinya notaris dari jabatannya sementara waktu, Bedasarkan Pasal 9 Peraturan Menteri Hukum dan Hak Asasi Manusia Nomor 25 Tahun 2004 Tentang Syarat dan Tata Cara Pengangkatan, Perpindaan, Pemberhentian dan Perpanjangan Masa Jabatan Notaris.

3. Pemberhentian dengan hormat

Pemberhentian dengan hormat, dikonsepkan berakhir atau selesainya notaris dalam menjalankan jabatannya sebagai notaris dengan cara-cara natural (alamiah), demi hukum, maupun karena keitidakmampuannya. Ada 5 (lima) alasan di berhentikan notaris dengan hormat dari jabatannya, bedasakan Pasal 38 Peraturan Menteri Hukum dan Hak Asasi Manusia Nomor 25 Tahun 2004 Tentang Syarat dan Tata Cara Pengangkatan, Perpindaan, Pemberhentian dan Perpanjangan Masa Jabatan Notaris.

4. Pemberhentian dengan tidak hormat.

Pemberhentian dengan Tidak hormat, dikonsepkan bahwa notaris melepas atau mengakhiri jabatan dengan cara tidak lazim atau tidak baik. Ada 4 (empat) alasan pemberhentian notaris dengan tidaj hormat, Bedasarkan Pasal 68 Ayat 1 Peraturan Menteri Hukum dan Hak Asasi Manusia Nomor 25 Tahun 2004 Tentang Syarat dan Tata Cara Pengangkatan, Perpindaan, Pemberhentian dan Perpanjangan Masa Jabatan Notaris.

Pengaturan tentang sanksi- sanksi notaris yang diatur didalam UUJN dan Kode Etik Notaris hanya bersifat administratif atau hanya mengatur sanksi administratif saja dan tidak mengatur mengenai sanksi pidana. Hal ini dapat dilihat dari pasal-pasal di dalam UUJN, Kode 
Etik dan peraturan pelaksana lainnya tidak ada yang mengatur mengenai sanksi pidana. Maka dari itu sanksi-sanksi yang diatur didalam UUJN dan Kode Etik hanya mengatur etiknya saja. Putusan yang dikeluarkan oleh Majelis Pengawas Pusat Notaris tidak berwenang dalam menjatuhkan sanksi pidana. Bila notaris yang akan dijatuhi sanksi pidana harus didaftarkan ke Pengadilan Negeri setempat untuk kemudian hakimlah yg menjatuhi sanksi pidana. Perbuatan yang dilakukan oleh notaris juga harus memenuhi unsur pelanggaran hukum yang dimuat dalam KUHP.

Pengaturan mengenai sanksi pidana terhadap notaris belum diatur secara khusus di dalam UUJN. Mekanisme penjatuhan sanksi pidana yang dilakukan notaris, contohnya apabila seorang notaris melakukan penggelapan dan penipuan mengikuti sistem penjatuhan sanksi pidana umum di dalam KUHP yakni Pasal 372 dan 378 KUHP. Notaris yang melakukan penggelapan dan penipuan dapat dijatuhi sanksi pidana yaitu pidana penjara paling lama 4 (empat) tahun dan denda paling banyak Sembilan ratus juta rupiah. Namun yang berhak menjatuhkan sanksi pidana tersebut adalah hakim di pengadilan negeri bukan majelis pengawas notaris maupun Menteri Hukum dan Hak Asasi Manusia.

Mekanisme penjtuhan sanksi yang diatur di dalam UUJN dan Kode Etik Notaris hanya sebagatas menjatuhkan sanksi administratif saja, yakni Peringatan tertulis, Pemberhentian sementara, Pemberhentian dengan hormat dan Pemberhentian dengan tidak hormat. Peringatan tertulis adalah sanksi paling ringan ringan dan pemberhentian dengan hormat atau tidak hormat adalah sanksi terberat Notaris. Ketika notaris mendapatkan sanksi yang diPutusakan oleh Majelis Pengawas Pusat Notaris untuk kemudian disahkan oleh Menteri Hukum dan Hak Asasi Manusia berupa sanksi pemecatan sementara aau pemberhentian maka kewenangannya sebagai seorang notaris dicabut dan notaris tidak berwenang lagi dalam membuat akta autentik. Akta -akta yang dibuat ketika notaris yang sedang dalam masa hukuman menjadi tidak autenik lagi atau menjadi akta dibawah tangan.

Apabila ada masyarakat yang merasa tidak cukup puas dengan sanksi etik saja dan ingin notaris tersebut dijatuhi hukuman pidana juga, mereka dapat menggugat notaris tersebut ke pengadilan Negeri dan menggugat ke Majelis Pengawas Notaris. Namun, tetap harus memenuhi unsure KUHP, syarat agar dapat menggugat notaris ke Pengadilan Negeri. 
Otentik's: Jurnal Hukum Kenotariatan (Vol 3, No. 1, Januari 2021)

p-ISSN 2655-5131 e-ISSN 2685-3612

Pada hakikatnya seorang Notaris yang melanggar ketentuan Pasal 16 Ayat 1 huruf a Undang-Undang Nomor 2 tahun 2014 tentang Perubahan Atas Undang-Undang Nomor 30 Tahun 2004 Tentang Jabatan Notaris, akan dijatuhi sanksi administratif sesuai dengan bedararkan Pasal 85 Undang-Undang Nomor 2 tahun 2014 tentang Perubahan Atas UndangUndang Nomor 30 Tahun 2004 Tentang Jabatan Notaris yang berbunyi “ Pelanggaran ketentuan sebagaimana dimaksud dalam Pasal 7, Pasal 16 ayat (1) huruf a, Pasal 16 ayat (1). huruf b, Pasal 16 ayat (1) huruf c, Pasal 16 ayat (1) huruf d, Pasal 16 ayat (1) huruf e, Pasal 16 ayat (1) huruf f, Pasal 16 ayat (1) huruf g, Pasal 16 ayat (1) huruf h, Pasal 16 ayat (1) huruf i, Pasal 16 ayat (1) huruf j, Pasal 16 ayat (1) huruf k, Pasal 17, Pasal 20, Pasal 27, Pasal 32, Pasal 37, Pasal 54, Pasal 58, Pasal 59, dan/atau Pasal 63, dapat dikenai sanksi berupa:a. teguran lisan, b. teguran tertulis, c. pemberhentian sementara, pemberhentian dengan hormat; atau d.pemberhentian dengan tidak hormat." Melihat sangat lusanya pemahaman sanksi administratif yang terdapat didalam Pasal 85 tersebut, disebabkan tidak adanya standart minimal dan maksimalnya penjatuhan sanksi yang akan dijatuhi oleh Majelis Pengawas Notaris. Pertimbangan yang terdapat didalam fakta hukum persidangan dan berat dan ringannya kesalahan yang dilakukan notaris serta faktor lainnya menjadi pertimbangan Majelis Pengawas Notaris untuk penjatuhan sanksi notaris tersebut. Maka, Majelis Pengawas Notaris sebagai lembaga idependen dalam melakukan pengawasan notaris harus bersikap professional dan bijaksana dalam memutuskan sanksi administratif. Hal ini menjadi penting untuk mengindari kesewenang -wenangannya dalam penjatuhan sanksi administratif dan menimbulkan ketidakadilan didalam lingkup notaris.

Pada hakikatnya, di dalam hukum pidana positif Indonesia, hakim mempunyai kebebasan yang sangat luas untuk memilih jenis pidana (strafsoort) yang dikehendaki sehubungan dengan penggunaan sistem alternative di dalam pengancaman pidana didalam Undang-Undang. Begitupun dalam Penjatuhan sanksi administratif oleh Majelis Pengawas Pusat Notaris, Majelis Pengawas Notaris sebagai lembaga yang berwenang dalam mengadili, memiliki kebebasan dalam penjatuhan sanksi kepada notaris bedasarkan pertimbangan-pertimbangan yang dimilikinya selama persidangan. Maka, bukan hal yang baru jika kita menemukan kasus notaris yang melakukan pelanggaran pasal yang sama namun penjatuhan sanksi yang berbeda. Majelis Pengawas dalam hal ini memiliki pertimbangan lainnya, antara lain berat ringannya kesalahan notaris, koopertaif atau tidaknya dan etika notaris dalam persidangan. 
Otentik's: Jurnal Hukum Kenotariatan (Vol 3, No. 1, Januari 2021)

p-ISSN 2655-5131 e-ISSN 2685-3612

Penjatuhan sanksi administratif yang berbeda atau disparitas putusan pada kedua kasus tersebut didasarkan pada pertimbangan berat dan ringannya pelaggaran yang dilakukan oleh notaris. Walaupun kedua notaris telah melanggar pasal yang sama, yakni Pasal 16 Ayat 1 huruf a Undang-Undang Nomor 2 tahun 2014 tentang Perubahan Atas Undang-Undang Nomor 30 Tahun 2004 Tentang Jabatan Notaris, namun tingkat kesalahan yang dilakukan oleh kedua notaris berbeda. Notaris MB dijatuhi sanksi pemberhentian sementara selama 3 (tiga) bulan dalam hal ini agar memberikan efek jera dan notaris D dijatuhi sanksi pemberhentian dengan hormat adalah karena tidak merasa jera dan selalu mengulang pelanggaran yang sama, maka Majelis dalam Perimbangannya menjatuhi hukuman Pemberhentian dengan hormat. Pemberhentian dengan hormat dijatuhi Karena Notaris D kooperatif dalam persidangan dan mengakui akan kesalahannya, alasan itulah Majelis Pengawas Menjatuhi pemberhentian dengan hormat, bukan pemberhentian dengan tidak hormat.

Namun seiring kali disparitas putusan banyak menimbulkan kontroversi dan permasalahan dalam keadilan di lingkungan notaris. Perbedaan penjatuhan sanksi administratif didasarkan pada kebebasan Majelis Pengawas Pusat untuk menentukan berat ringannya palanggaran, sebab dalam Undang-Undang hanya mengatur adalah masksimum dan minimumnya sanksi saja. Hal ini sering menjadi masalah keadilan didalam lingkungan notaris.

Diaparitas putusan apabila dikaitkan dengan teori keadilan menurut W.J.S Poerwadarminto dalam Kamus Besar Bahasa Indonesia, yang menggemukakan bahwa pengertian keadilan ialah tidak berat sebelah yang artinya seimbang, dan yang sepatutnya tidak sewenang-wenang. Namun dalam kasus diatas tidak sesuai dengan ciri-ciri keadilan menurut WJS Poerwadarminto, bahwa keadilan adalah tidak berat sebelah atau seimbang, dan sepatutnya tidak sewenang. Dalam pejatuhan sanksi administratif pada notaris pada hakikatnya notaris yang melanggar Pasal yang sama akan dijatuhi sanksi yang sama atau seimbang dan Majelis Pengawas Notaris tidak boleh sewenang-wenang dalam menjatuhkan sanksi karena tidak ada standart maksimum dan minimum penjatuhan sanksi administratifdi dalam Undang-Undang Nomor 2 tahun 2014 tentang Perubahan Atas Undang-Undang Nomor 30 Tahun 2004 Tentang Jabatan Notaris. Namun dalam kasus diatas disparitas putusan telihat sangat signifikan pada penjatutan sanksi administratif, notaris yang melakukan pelanggaran yang sama,yaitu Pasal 16 Ayat 1 huruf a Undang-Undang Nomor 2 tahun 2014 tentang Perubahan Atas Undang-Undang 
Otentik's: Jurnal Hukum Kenotariatan (Vol 3, No. 1, Januari 2021)

p-ISSN 2655-5131 e-ISSN 2685-3612

Nomor 30 Tahun 2004 Tentang Jabatan Notaris, namun mendapat sanksi yang berbeda. Notaris MB mendapatkan sanksi pemberhentian sementara selama 3 (tiga) bulan dan Notaris D mendapat sanksi pemberhentian dengan hormat. Disparitas ini terjadi karna perbedaan pertimbangan Majelis Pengawas Pusat dalam menjatuhkan sanksi administratif dan seringkali menimbulkan ketidakadilan dalam lingkungan notaris.

Bedasarkan Undang-Undang Nomor 2 tahun 2014 tentang Perubahan Atas UndangUndang Nomor 30 Tahun 2004 Tentang Jabatan Notaris mengatur Majelis Pengawas Pusat Notaris memiliki kewenangan untuk memanggil, meyelenggarakan sidang dan memutuskan sanksi sesuai dengan pertimbangannya namun harus tetap bedasarkan takaran Undang-Undang . Hal ini sesuai dengan asas nulla poena sine lege yang memberi batas kepada hakim untuk memutuskan sanksi pidana berdasarkan takaran yang sudah ditentukan dalam peraturan perundang-undangan. Sehingga dalam menjatuhkan sanksi Administratif Majelis Pengawas Pusat memiliki pertimbangan-pertimbangannya sendiri namun harus tetap pada takarannya seperti apa yang terdapat pada kasus ini.

Putusan yang dikeluarkan oleh Majelis Pengawas Pusat merupakan putusan yang inchrat dan bersifat final. Maka, notaris yang sudah diputuskan oleh Majelis Pengawas Pusat harus tunduk kepada putusan tersebut dan putusan Majelis Pengawas Pusat bersifat mengikat sejak putusan tersebut dibacakan di hadapan notaris dan tidak dapat diganggu gugat. Notaris yang merasa keberatan dengan hasil putusan Majelis Pengawas Pusat dapat menggugat putusan tersebut kepada Pengadilan Tata Usaha Negara karena Putusan yang dikeluarkan oleh Majelis Pengawas Pusat merupakan produk Tata Usaha Negara sebagai produk dibawah payung hukum instansi Kementrian Hukum dan Hak Asasi Manusia sebagai lembaga pemerintahan.

\section{KESIMPULAN}

Kekuatan hukum mengikat Putusan Majelis Pengawas Pusat Notaris terhadap UndangUndang Jabatan Notaris dan Kode Etik Notaris adalah baik didalam Undang-Undang Jabatan Notaris dan Kode Etik Notaris hanya mengatur hal-hal administraif atau Etik dari profesi notaries saja. Hal ini dapat dilihat bahwa Undang-Undang Jabatan Notaris dan Kode Etik Notaris hanya mengatur penjatuhan sanksi administratif dan tidak mengatur sanksi pidana. Maka, Putusan Majelis Pengawas Pusat Notaris hanya memuat sanksi administratif, yaitu sanksi peringatan tertulis, sanksi pemberhenian sementara, sanksi pemberhentian dengan hormat dan 
Otentik's: Jurnal Hukum Kenotariatan (Vol 3, No. 1, Januari 2021)

p-ISSN 2655-5131 e-ISSN 2685-3612

sanksi pemberhentian dengan tidak hormat. Dan Pertimbangan Majelis Pengawas Pusat Notaris dalam putusan No. 03/B/MPPN/X/2018 dan Putusan No. 13/B/MPPN/XII/2017 adalah keduanya telah melanggar pasal yang sama yaitu Pasal 16 Ayat 1 huruf a Undang-Undang Nomor 2 tahun 2014 tentang Perubahan Atas Undang-Undang Nomor 30 Tahun 2004 Tentang Jabatan Notaris namun terdapat disparitas dalam penjatuhan sanksi kepada kedua notaris, yakni pada putusan Putusan No. 13/B/MPPN/XII/2017, Notaris MB dijatuhi pemberhentian sementara 3 bulan dan pada Putusan No. 03/B/MPPN/X/2018, Notaris D dijatuhi pemberhentian dengan homat. Hal ini didasarkan pada pertimbangan berat dan ringannya kesalahan yang dilakukan oleh kedua notariss dan fakta-fakta hukum yang muncul didalam persidangan, seperti telapor menyesali perbuatannya dan didalam persidangan terlapor kooperatif dan tidak berbelit-belit. Notaris MB melakukan pelanggaran untuk pertama kalinya sehingga Majelis Pengawas Pusat menjatuhi sanksi pemberhentian sementara selama 3 bulan untuk memberikan efek jera dan diharapkan Notaris MB tidak akan melakukan perbuatannya lagi, sedangkan untuk Notaris D, telah melakukan pelanggaran berat berulang-ulang dan tidak pernah jera, sehingga Majelis Pengawas Pusat menjatuhi sanksi pemberhentian dengan hormat.

\section{DAFTAR PUSTAKA}

\section{A. Buku-buku}

Abdullah, Pembatasan Upaya Hukum Kasasi Pidana Untuk Mewujudkan Asas Peradilan Sederhana, Cepat dan Biaya Ringan, Laporan Penelitian, Jakarta, Puslitbang Hukum dan Peradilan Badan Litbang Diklat Kumdil Mahkamah Agung RI, 2011.

Afrizal, Metode Penelitian Kualitatif Sebuah Upaya Mendukung Penggunaan Penelitian Kualitatif Dalam Berbagai Disiplin Ilmu, PT. Raja Grafindo Persada, Jakarta, 2014.

Adjie Habib, Hukum Notaris Indonesia Tafsir Temaik Terhadap UU No. 30 Tahun 2004 Tentang Jabatan Notaris, Refika Aditama, Bandung, 2008.

Adjie Habib, Sanksi Perdata dan Administratif Terhadap Notaris Sebagai Pejabat Publik, Bandung, Refika Aditama, 2008.

Ashofa Burhan, Metode Penelitian Hukum, Jakarta,Rineka Cipta,1998.

Chand, Hari. Modern Jurisprudence. Kuala Lumpur. International Law Book Services. 1994.

Ghofur Abdul, Lembaga Kenotariatan Indonesia: Perspektif Hukum dan Etika, Yogyakarta, UII Press, 2009. 
G.H.S Tobing Lumban,. Peraturan Jabatan Notaris, Jakarta, Erlangga, 1996.

Gie The Liang, Teori-teori Keadilan, Yogyakarta, Sumber Sukses, 2002.

Joachim Carl Friedrich, Filsafat Hukum Perspektif Historis, Bandung, Nuansa dan Nusamedia, 2004.

Kanter E.Y., Etika Profesi Hukum: Sebuah Pendekatan Religius, Storia Grafika, Jakarta, 2001.

Kelsen Hans, General Theory of Law and State, diterjemahkan oleh Rasisul Muttaqien, Bandung, Nusa Media, 2011.

Lumban G.H.S Tobing, Peraturan Jabatan Notaris (Notaris Reglement), Erlangga, Jakarta, 1999.

Mahmud Peter Marzuki, Penelitian Hukum, Jakarta, Kencana, 2006.

Merokusumo, Hati Nurani Hakim dan Putusannya, dalam Antonius Sudirman, ,Bandung, Citra Aditya Bakti, 2007.

Mohamad Pan Faiz, Teori Keadilan John Rawls, dalam Jurnal Konstitusi, Volue 6 Nomor 1 April 2009.

M.Philipus Hadjon, dkk, Pengantar Hukum Administrasi Negara, Gajah Mada University Press, Yogyakarta, 2002.

Muhammad Abdulkadir, Etika Profesi Hukum, cet.3, PT.Citra Aditya Bakti, Bandung, 2006.

Muladi dan Barda Nawawi Arief, Teori-teori Dan Kebijakan Pidana, Bandung, Alumni , 2005.

Pengurus Pusat Ikatan Notaris Indonesia, Jati Diri Notaris Indonesia Dulu,Sekarang dan Di Masa Akan Datang, Jakarta, PT. Gramedia Sinar Pustaka, 2009.

Poerwadarminta W.J.S, Kamus Umum Bahasa Indonesia, Balai Pustaka, Jakarta, 1984.

Salim H., Peraturan Jabatan Notaris, Jakarta, Sinar Grafika, 2018.

Soegondo R. Notodisoerjo, Hukum Notariat Di Indonesia Suatu Perjelasan, Jakarta, Raja Grafindo Persada, 1993.

Soekanto Soerjono dan Sri Mamudji, Penelitian Hukum Normatif (Suatu Tinjauan Singkat), Rajawali Pers, Jakarta, 2001.

Thamrin Husni,, Pembuatan Akta Pertanahan oleh Notaris, Laksbang Pressindo, Yogyakarta, 2011.

\section{B. Perundang-Undangan}

Indonesia. Undang-Undang Dasar 1945.

Kitab Undang-Undang Hukum Perdata (Burgerlijk Wetboek), Terjemahan R. 
Kitab Undang-Undang Hukum Pidana, Terjemahan R.

Undang-Undang Nomor 2 tahun 2014 tentang Perubahan Atas Undang-Undang Nomor 30 Tahun 2004 Tentang Jabatan Notaris.

Peraturan Menteri Hukum dan Hak Asasi Manusia Republik Indonesia Nomor M.02. PR.08.10 Tahun 2004 Tentang Tata Cara Pengangkatan Anggota, Pemberhentian Anggota, Susunan Organisasi,Tata Kerja,Dan Tata Cara Pemeriksaan Majelis Pengawas Notaris.

Putusan No. 03/B/MPPN/X/2018 dan Putusan Nomor 13/B/MPPN/XII/2017. Kode Etik Notaris

\section{Sumber Lain}

https://www.hukumonline.com/berita/baca/lt524a2ce258cb5/disparitas-putusan-danpemidanaan-yang-tidak-proporsional/, diakses pada Kamis, 18 Juli 2019.

Hasil wawancara Bapak Rahmat Riyanto,S.H.,M.M, bagian Kepala SubDirektorat Notaris Pusat Pada Direktorat Perdata Ditjen AHU, pada hari Senin, 24 Juni 2019.

Wawancara Bapak Daking Setyono, S.H., M.H., M.Kn., Ketua Majelis Pengawas Daerah Notaris Kab. Bogor, pada hari kamis, 20 Juni 2019. 